\title{
Penanaman Nilai-Nilai Pendidikan Agama Islam pada Peserta Didik di Pesantren Ummusshabri Kota Kendari
}

\section{Pairin}

\section{Fakultas Tarbiyah dan Ilmu Keguruan IAIN Kendari}

Email: pairin@iainkendari.ac.id

\begin{abstract}
Abstrak
Ajaran Islam merupakan pedoman perilaku dari para pemeluknya, lebih luas lagi bagi alam semesta. Karenanya sosialisasi ajaran Islam pada masyarakat mesti dilakukan secara terorganisasi melalui lembaga pendidikan, terutama lembaga pendidikan Islam seperti pesantren. Perkembangan kekinian yang menunjukkan kemunduran etik masyarakat adalah penanda pentingnya penanaman nilai-nilai pendidikan agama Islam sejak dini. Upaya ini akan memberi sumbangan besar atas persoalan kebangsaan dalam konteks yang lebih luas. Pesantren Ummusshabri sebagai salah satu lembaga pendidikan Islam tertua di Sulawesi Tenggara telah menunjukkan peran besar dalam pendidikan dan kehidupan keberagamaan di Sulawesi Tenggara, sehingga penting dikaji. Penelitian ini bertujuan untuk memahami penanaman nilai-nilai pendidikan agama Islam pada peserta didik di Pondok Pesantren Ummusshabri Kendari. Dua hal yang didalami yakni: nilai-nilai pendidikan agama Islam pada peserta didik, dan proses penanaman nilai-nilai pendidikan agama Islam pada peserta didik. Untuk menjawab masalah penelitian, digunakan pendekatan kualitatif dengan metode deksriptif. Data dikumpulkan melalui wawancara, pengamatan, dan studi dokumen. Data yang terkumpul dianalis dengan tahapan reduksi data, penyajian data, dan verifikasi. Hasil penelitian menunjukkan bahwa nilai-nilai pendidikan agama Islam pada peserta didik Pondok Pesantren Ummusshabri Kendari mencakup: kedisiplinan, kesopanan, tanggung jawab, dan kepedulian sosial. Ikhtiar yang dilakukan dalam rangka menjaga nilainilai pendidikan agama Islam peserta didik meliputi: pengawasan dan pemberian sanksi educatif, pembiasaan, menciptakan lingkungan santun, permberdayaan OSIS, serta membudayakan kerja sama dan tolong menolong.
\end{abstract}

\section{Kata Kunci: Nilai, Pendidikan Islam, Pesantren}




\title{
Planting the Values of Islamic Religious Education for Students in the Islamic Boarding School of Ummusshabri Kendari City
}

\section{Pairin}

\author{
Tarbiyah Faculty and Teacher Training of IAIN Kendari \\ Email: pairin@iainkendari.ac.id
}

\begin{abstract}
Islamic teachings are the behavioral guidelines of their adherents, more broadly for the universe. Therefore the socialization of Islamic teachings in society must be carried out in an organized manner through educational institutions, especially Islamic education institutions such as Islamic boarding schools. Current developments that show the decline of ethics in society are a sign of the importance of planting the values of Islamic religious education from an early age. This effort will make a major contribution to the issue of nationalism in a broader context. The Ummusshabri Islamic Boarding School as one of the oldest Islamic educational institutions in Southeast Sulawesi has shown a large role in education and religious life in Southeast Sulawesi, so it is important to study it. This study aims to understand the planting of the values of Islamic religious education for students at the Ummusshabri Islamic Boarding School in Kendari. Two things were explored, namely: the values of Islamic religious education for students, and the process of planting the values of Islamic religious education for students. To answer the research problem, a qualitative approach is used with a descriptive method. Data is collected through interviews, observations, and document studies. The data collected is analyzed by stages of data reduction, data presentation, and verification. The results showed that the values of Islamic religious education in students of Kendari's Ummusshabri Islamic Boarding School included: discipline, politeness, responsibility, and social care. The efforts taken to safeguard the values of the Islamic religious education of students include: supervision and giving educative sanctions, habituation, creating a polite environment, empowering the student council, and cultivating cooperation and help.
\end{abstract}

Keywords: Value, Islamic Education, Pesantren 


\section{Pendahuluan}

Pendidikan pesantren diakui sebagai persekolahan tertua dan khas Indonesia ${ }^{1}$. Bahkan sangat sulit menemukan warisan persekolahan jaman pra kolonial selain pesantren ${ }^{2}$. Dengan demikian, pesantren bagi masyarakat Indonesia, terutama pada masa pra kolonial hingga masa kolonial adalah wahana pendidikan yang sangat merakyat. Dominasi pendidikan oleh kalangan bangsawan maupun penjajah, menjadikan pesantren sebagai primadona bagi sebagian besar masyarakat, terutama di Pulau Jawa.

Dalam perkembangan kekinian, pesantren telah menjadi milik berbagai kalangan. Tidak hanya berkutat pada wilayah-wilayah keagamaan an sich, tetapi telah merambah wilayah-wilayah profan. Hasilnya, pesantren menjadi salah satu penyumbang terbesar Sumber Daya Manusia dalam pembangunan nasional. Bahkan secara kelembagaan, sebagai contoh, PM Gontor membuktikan diri sebagai korporasi pesantren dan persekolahan terbesar di Indonesia ${ }^{3}$.

Fakta-fakta kesuksesan pesantren hingga kini, adalah perwujudan dari sistem pendidikan pesantren yang mentransformasikan nilai-nilai pendidikan agama Islam. Pendidikan pesantren tidak hanya mengajarkan doktrin keagamaan, tetapi menerapkannya dalam berbagai bentuk kegiatan di dalamnya. Karenanya lulusan pesantren selalu dapat berkiprah pada berbagai bidang kehidupan kemasyarakatan.

Ummusshabri adalah salah satu pesantren di Sulawesi Tenggara yang menarik diperhatikan. Sebagai pesantren tertua di Sulawesi Tenggara, Ummu Shabri telah membuktikan diri sebagai penyumbang SDM dalam pembangunan di berbagai bidang, lokal dan nasional. Pembenahan kelembagaan juga terus-menerus dilakukan, sehingga saat ini menjadi salah satu persekolahan favorit di Kota Kendari. Kondisi ini terutama terlihat ketika dicanangkannya program

1 Syahrul, Syahrul. "Kepemimpinan dan Inovasi Lembaga Pendidikan (Pengalaman Pondok Gontor VII Putra Sulawesi Tenggara)." Al-Ta'dib 8, no. 1 (2015): 82-100.

2 Syahrul, Syahrul. "Perjumpaan Demokrasi, Multikulturalisme dan Inklusifisme Pendidikan di PM Gontor 7 Putera, Konawe Selatan." Shautut Tarbiyah 38, no. 24 (2018): 163-180.

${ }^{3}$ RELIGIO-TRANSFORMASIONAL, K. E. P. E. M. I. M. P. I. N. A. N., SYAHRUL MARHAM, and IHWAN FAUZI. "EKSEKUTIF SUMMARY." 
CIBI-CIBER ${ }^{4}$. Program ini memadukan berbagai aspek dalam perkembangan peserta didik, seperti ilmu pengetahuan, akhlak, wawasan kebangsaan, kearifan lokal, maupun global. Menariknya, semangat program ini berangkat dari semangat keagamaan (Islam).

Sebagai sebuah agama, Islam merupakan seperangkat ajaran yang mengandung nilai-nilai yang dibutuhkan oleh penganutnya. Nilai-nilai tersebut terpancar dalam perilaku keberagamaan. Sejalan dengan pandangan Daradjat dkk bahwa "nilai itu adalah suatu perangkat keyakinan ataupun perasaan yang diyakini sebagai suatu identitas yang memberikan corak yang khusus kepada pola pemikiran, perasaan, keterikatan, maupun perilaku" ${ }^{5}$.

Proses penanaman nilai-nilai keislaman dapat berlangsung pada lingkungan keluarga, sekolah, dan masyarakat. Tetapi nampaknya, persekolahan lebih terorganisir dan sistematis dalam proses penanaman nilai-nilai keislaman itu. Dalam konteks inilah, Pesantren Ummusshabri mengambil peran mengenalkan nilai-nilai agama Islam sejak dini, yang kemudian dilanjutkan pada tingkat yang lebih tinggi.

\section{Metode Penelitian}

Penelitian ini menggunakan pendekatan kualitatif dengan metode deksriptif, penyelidikan pada kondisi alamiah dengan menjadikan teori sebagai pisau analisis ${ }^{6}$. Pengumpulan data dilakukan melalui wawancara, pengamatan, dan studi dokumen ${ }^{7}$. Data yang terkumpul dianalisis dengan menggunakan model dari Miles dan Huberman, dengan tahapan reduksi data, display data, dan penarikan kesimpulan (verifikasi) ${ }^{8}$. Pengujian keabsahan data dilakukan melalui

4 Marham, Syahrul. "Full Day School: Kontroversi Dan Fenomena Kebangkitan Pendidikan Berbasis Masyarakat Di Kota Kendari.” OSF, June 2, 2019. osf.io/wkc8b.

${ }^{5}$ Daradjat, Zakiah, A. Sadali, Yusuf Amer Feisal, Zaini Muchtarom, M. Abduh Malik, and Ahmad Basyar. Dasar-dasar agama Islam: buku teks pendidikan agama Islam pada perguruan tinggi umum. Bulan Bintang, 1984.

${ }^{6}$ Bungin, Burhan. Penelitian kualitatif: komunikasi, ekonomi, kebijakan publik, dan ilmu sosial lainnya. Kencana, 2007.

7 Moleong, Lexy J. "Metodologi penelitian kualitatif edisi revisi." Bandung: PT Remaja Rosdakarya 103 (2007).

${ }^{8}$ Miles, Matthew B., and A. Michael Huberman. Analyzing qualitative data: A sourcebook of new methods. Center for Policy Research, 1983. 
proses member check, trianggulasi, perpanjangan pengamatan, peningkatan ketekunan, dan uji keteralihan?

\section{Nilai-nilai Pendidikan Islam pada Peserta Didik di Pesantren Ummusshabri Kota Kendari}

Nilai-nilai pendidikan Islam, sangat penting untuk diterapkan dalam lingkungan pendidikan, khususnya di pesantren. Apalagi melihat perkembangan kehidupan peserta didik dewasa ini yang semakin hari semakin jauh dari nilai-nilai pendidikan Islam maka eksistensi nilai-nilai pendidikan sangat penting untuk diterapkan.

Berkaitan dengan hal tersebut, ada beberapa hal yang penulis identifikasi sebagai bentuk gambaran nilai-nilai pendidikan Islam pada peserta didik di Pesantren Ummusshabri Kota Kendari yaitu:

\section{Kedisiplinan}

Kedisiplinan merupakan salah satu bagian daripada akhlak mulia. Kedisiplinan sangat penting bagi kehidupan manusia. Oleh karena itu, kedisiplinan harus selalu ditanamkan agar menjadi suatu kebiasaan. Orang yang berhasil dalam bidang pekerjaan, umumnya mempunyai kedisiplinan yang tinggi, sebaliknya orang yang mengalami kegagalan umumnya mempunyai kedisiplinan yang rendah. Kedisplinan dalam lingkungan sekolah pada kusususnya, sangat dibutuhkan dalam upaya mewujudkan kualitas sekolah yang baik. Karena itu, kedisiplinan seharusnya dibudayakan oleh setiap sekolah. Sebagaimana halnya dengan guru mata pelajaran agama Islam di sekolah yang selalu memberikan keteladanan tentang disiplin, peserta didik harus juga dibiasakan untuk melakukan hal yang serupa. Penelitian ini menemukan bahwa masalah kedisiplinan waktu peserta didik di pesantren tidak dikhawatirkan lagi karena mereka mondok bersama guru dan kakak pembinanya di pesantren sehingga segala aktivitasnya selalu dikontrol dengan baik.

Kedisiplinan dalam mengikuti tata tertib di pesantren sangat penting untuk dibiasakan kepada peserta didik. Apabila kebiasaan ini sudah tertanam dalam diri peserta didik maka tentu akan terbawa nantinya sampai menuju kedewasaan bahkan tidak menutup kemungkinan hal tersebut menjadi karakter bagi peserta didik.

${ }^{9}$ Sugiyono, Prof. "Dr. 2010." Metode Penelitian Kuantitatif, Kualitatif, dan $R \& D$. Bandung: CV Alfabeta. 
Pembiasaan sikap kedisiplinan di pesantren ini sudah lama diterapkan dan bukan hanya kuhusus kepada peserta didik saja tetapi semua warga pesantren tanpa terkecuali. Khusus mengenai kedisiplinan waktu peserta didik, jarang lagi yang ditemukan terlambat datang ke sekolah karena apabila terlambat maka mereka dikuncikan pintu sehingga tidak boleh lagi masuk. Adapun masalah keterlambatan pulang sekolah, tetap masih ada yang biasa ditemukan karena mereka terkadang tinggal di sekolah sampai sore jika ada kegiatan yang berkaitan dengan kepentingan sekolah.

\section{Kesopanan dalam bertutur kata}

Kesopanan dalam bertutur kata merupakan salah satu bagian daripada nilai-nilai pendidikan Islam. Oleh karena itu, nilai-nilai pendidikan Islam tersebut sangat penting untuk dilakukan dan dibiasakan kepada peserta didik.

Kesopanan peserta didik dalam bertutur kata sesama guru khususnya di Pesantren Ummusshabri Kota Kendari, sudah termasuk baik. Hal tersebut terlihat ketika peserta didik beribicara dengan guru, mereka selalu mengeluarkan bahasa yang lemah lembut dan tidak pernah ditemukan peserta didik yang membentak-bentak gurunya. Meskipun masih ditemukan juga praktik komunikasi antar peserta didik yang berbeda. Karenanya para guru secara terus menerus selalu mengingatkan bahwa sopan santun dalam bertutur kata tidak hanya pada guru, tetapi juga berlaku untuk sesama peserta didik.

\section{Tanggung Jawab}

Sikap tanggung jawab terhadap amanah yang diemban harus dilaksanakan dengan baik karena sikap tanggung jawab merupakan salah satu sikap yang sangat dianjurkan di dalam Islam. Termasuk dalam hal ini adalah tanggung jawab dalam melaksanakan tugas yang diemban. Tanggung jawab adalah salah satu ajaran pokok dari agama Islam. Oleh karena itu, manusia sebagai makhluk yang sempurna harus memiliki sikap tanggung jawab dalam melaksanakan segala amanah yang diembannya. Manusia diciptakan oleh Allah swt. mengalami periode lahir, hidup, kemudian mati. Agar manusia dalam hidupnya mempunyai harga sebagai pengisi fase kehidupannya itu maka manusia tersebut atas namanya sendiri dibebani tanggung jawab. Sebab apabila tidak ada tanggung jawab terhadap dirinya sendiri maka tindakannnya tidak terkontrol lagi. Intinya dari masing- 
masing individu dituntut adanya tanggung jawab untuk melangsungkan hidupnya di dunia sebagai makhluk Allah. Sebagai contoh, manusia mencari makan tidak lain adalah karena adanya tanggung jawab terhadap dirinya sendiri agar dapat melangsungkan hidupnya.

Berkaitan dengan hal tersebut, ganbaran nilai-nilai pendidikan Islam peserta didik di Pesantren Ummusshabri Kota Kendari, khususnya yang terkait dengan sikap tanggung jawab, terlihat ketika melaksanakan tugas yang diberikan oleh guru, seperti protokol, dan kultum ketika selesai salat, serta membersihkan kelas, termasuk baik karena mereka selalu melaksanakannya dengan penuh semangat dan penuh rasa tanggung jawab. Hal ini juga nampak pada usaha mempersiapkan diri dengan baik.

Pembiasaan peserta didik untuk melaksanakan tugas yang diberikan oleh guru, seperti azan, kultum di masjid setiap selesai salat, merupakan salah satu bentuk penerapan sikap tanggung jawab. Apabila hal ini dibiasakan oleh peserta didik maka tentu akan berpengaruh nantinya ketika ke luar dari lingkunga pesantren, yaitu memiliki sikap tanggung jawab dalam melaksanakan tugas yang diamanahkan kepadanya.

Tanggung jawab adalah salah satu amanah yang harus dilaksanakan oleh setiap individu. Apabila amanah tersebut diabaikan atau tidak dilaksanakan maka pasti akan memiliki dampak yang sangat berbahaya. Amanah sangat erat kaitannya dengan sikap tanggung jawab. Oleh karena itu, setiap amanah yang diberikan harus dipertanggungjawabkan.

Pemberian tugas kepada peserta didik di sekolah merupakan salah satu bentuk amanah yang harus dipertanggungjwabkan. Oleh karena itu, seorang guru harus banyak memberikan tugas kepada peserta didik untuk melatih peserta didik dalam melaksanakan tugas dan tanggung jawab yang diembannya.

Pada tingkat Madrasah Ibtida'yah boleh dikatakan masih kurang dalam hal pelaksanaan tugas dan tanggung jawab. Seperti ketika diberi tugas kultum dan MC secara bergiliran di Masjid terkadang mereka masih lebih banyak rasa malunya atau kurang percaya diri sehingga mereka kurang maksimal dalam melaksanakan tugas dan tanggung jawabnya. Hal ini dapat dipahami karena pada jenjang MI, peserta didik masih dalam tahap membangun fondasi nilai. 
Mencermati beberapan penuturan informan tersebut maka dapat disimpulkan bahwa gambaran nilai-nilai pendidikan Islam pada peserta didik di Pesantren Ummusshabri Kota Kendari, khususnya yang terkait dengan sikap tanggung jawab dalam melaksanakan tigas yang diamanhkan kepadanya sangat bervariasi. Artinya bahwa sikap tanggung jawab peserta didik tersebut, ada yang sudah mampu menerapkan dengan baik dan ada pula yang belum mampu menerapkannya dengan baik. Oleh karena itu, masih perlu upaya maksimal yang harus dilakukan oleh guru agar peserta didiknya mampu menerapkan sikap tanggung jawab dengan baik sebagaimana yang diharapkan.

\section{Kepedulian sosial}

Nilai kepedulian sosial peserta didik sangat penting untuk diperhatikan dan harus dibiasakan di dalam lingkungan pesantren karena kepedulian sosial merupakan salah satu bentuk nilai-nilai pendidikan Islam yang dapat mewujudkan kehidupan yang harmonis, di dalam lingkungan pesantren dan di lingkungan masyarakat pada umumnya.

Sehubungan dengan hal tersebut, gambaran nilai-nilai pendidikan Islam peserta didik di Pesantren Ummusshabri Kota Kendari, khususnya yang terkait dengan nilai-nilai kepedulian sosial, terlihat ketika ada peserta didik yang sakit, mereka berbarengan untuk mengantarkannya ke ruang UKS. Sekalipun demikian tetap juga masih perlu diupayakan agar semua peserta didik bisa memiliki kepedulian sosial.

Sikap kepedulian sosial yang dimiliki oleh peserta didik di Pesantren Ummusshabri Kota Kendari masih perlu banyak pembinaan karena masih ditemukan peserta didik yang masih memiliki tingkat kepedulian sosial yang rendah. Seperti pada saat belajar di dalam kelas, ada di antara temannya yang kebetulan polpennya macet dan ketika minta pulpen sesama temannya untuk dipinjam ternyata temannya yang punya pulpen dua, lama baru mereka mau meminjamkannya. Hal itu, merupakan salah satu bukti bahwa nilainilai pendidikan Islam peserta didik di Pesantren Ummusshabri Kota Kendari, khususnya yag terkait dengan sikap kepedulian sosial masih perlu banyak mendapatkan pembinaan agar sikap kepedulian sosial peserta didik di Pesantren Ummusshabri Kota Kendari semakin baik. 
Kemampuan peserta didik untuk mengumpulkan uang dalam rangka membantu teman-temannya yang sedang sakit merupakan salah satu bentuk kepedulian sosial yang tinggi dan harus dipertahankan oleh peserta didik. Apabila peserta didik sudah terbiasa dari awal bersedekah untuk teman-temannya yang sedang sakit maka tentu akan tebiasa nantinya ketika menuju pada kedewasaan. Sikap kepedulian sosial peserta didik sangat penting untuk selalu dibiasakan sejak anak-anak agar ketika nantinya menjadi orang dewasa maka mereka akan terbawa dengan kebiasaannya tersebut sehingga tidak sulit lagi mengaktualisasikan nilai-nilai kepedulian sosal terhadap siapa pun dan dimanapun mereka berada.

Gambaran nilai-nilai pendidikan Islam peserta didik di lingkungan pesantren Ummusshabri Kota Kendari, khususnya yang terkait dengan sikap kepedulian sosial terhadap sesama temannya sudah cukup baik. Seperti jika ada di antara temannya yang sakit meraka selalu bersama-sama untuk mengunjunginya sambil membawa berbagai makanan untuk temannya yang sedang sakit. Selain itu, apabila ada teman-temannya yang sakit mereka mengantarkannya ke puskesmas untuk melakukan perawatan.

Ketika ada temannya yang sedang sakit mereka biasanya mengumpulkan uang untuk membeli makanan lalu kemudian dibawakan kepada temannya yang sedang sakit. Oleh karena itu, peserta didik dipesantren ini apabila dilihat dari aspek kepedulian sosialnnya terhadap sesama teman-temannya sudah tersmasuk cukup baik. Sekalipun demikian, saya akui bahwa tetap masih perlu upaya maksimal untuk meningkatkannya karena masih ada juga sebagian dari temannya yang memiliki sikap kepedulian sosial yang rendah terhadap sesama temannya.

Dapat disimpulkan bahwa sikap kepedulian sosial peserta didik terhadap sesama teman-temannya di dalam lingkungan pesantren tetap masih perlu lagi lebih ditingkatkan karena masih ada sebagian peserta didik yang ditemukan memiliki sikap kepedulian sosial yang masih rendah. Artinya bahwa masih ada juga peserta didik yang terkadang bersifat acuh terhadap temannya yang sedang membutuhkan pertolongan. Sehingga dengan begitu maka perlu ada upaya profesional yang dilakukan oleh seluruh pihak pesantren agar sikap kepedulian sosial tersebut dapat tertanam dalam diri setiap peserta didik yang ada di dalam lingkungan pesantren tersebut. 


\section{Penanaman Nilai-nilai Pendidikan Islam pada Peserta Didik di Pesantren Ummusshabri Kota Kendari}

Nilai-nilai pendidikan Islam sangat penting untuk dikembangkan dalam lingkungan lingkunga pendidikan karena apabila nilai-nilai pendidikan Islam dikembangkan dalam lingkungan pendidikan seperti di pesantren maka tentu akan mudah tercipta suasana kehidupan yang harmonis. Dengan begitu maka kerukunan antara peserta didik dapat terwujud dengan baik.

Berkaitan dengan hal tersebut ada beberapa hal yang penulis identifikasi sebagai suatu bentuk upaya dan cara guru mata pelajaran agama Islam menanamkan nilai-nilai pendidikan Islam pada peserta didik di Pesantren Ummusshabri Kota Kendari, khususnya nilai-nilai pendidikan Islam yang terkait dengan kedisiplinan, kesopanan, tanggung jawab, dan kepedulian sosial. Bentuk penanaman nilai-nilai pendidikan Islam tersebut dapat dapat diuraikan sebagai berikut:

\section{Pengawasan dan Sanksi Edukatif}

Kedisiplinan merupakan salah satu bentuk nilai-nilai pendidikan Islam yang sangat penting ditanamkan dalam diri peserta didik sehingga apabila hal tersebut tertanam dalam diri peserta didik maka tentu akan mudah melaksanakan tugasnya dengan baik di dalam lingkungan sekolah.

Berkaitan dengan hal tersebut, ketika penulis melakukan observasi dan wawancara dengan informan ada beberapa cara yang dilakukan oleh guru mata pelajaran agama Islam dalam menanamkan nilai pendidikan Islam, khususnya yang terkait dengan nilai kedisiplinan. Misalnya guru mata pelajaran agama Islam mengontrol kehadiran peserta didik dalam kegiatan salat berjamaah dan dibantu oleh masing-masing ketua kelas. Setiap pelaksanaan salat berjamaah, peserta didik dicatat namanya yang selalu terlambat datang salat berjamaah. Apabila pelaksanaan salat sudah selesai maka peserta didik yang selalu terlambat diberi sanksi dalam bentuk mendidik, seperti membersihkan masjid, WC, dan pekarangan masjid.

Para guru mata pelajaran agama Islam di pesantren ini selalu membiasakan peserta didik untuk menerapkan nilai kedisiplinan dalam lingkungan pesantren, seperti dalam pelaksanaan salat berjamaah kami selalu mengontrol kehadiran peserta didik dengan dibantu oleh seluruh ketua kelas pada masing-masing kelas. Hal ini dilakukan dengan tujuan untuk menanamkan nilai-nilai kedisiplinan di 
dalam diri peserta didik khususnya dalam pelaksanaan salat berjamaah di lingkungan pesantren.

\section{Pembiasaan}

Salat berjamaah yang sebagai salah satu bentuk pengamalan nilai-nilai pendidikan Islam perlu dibiasakan untuk dilaksanakan bagi peserta didik di dalam lingkungan pesantren. Salat yang dilaksanakan lima kali dalam sehari semalam, sesungguhnya tidak dapat dikontrol secara keseluruhan oleh guru. Namun dengan upaya penanaman kesadaran dan pembiasaan di lingkungan pendidikan formal diharapkan mampu menjadi ibadah tersebut sebagai bagian dari kehidupan peserta didik. Kegiatan salat berjamaah di pesantren Ummusshabri Kota Kendari, sekalipun dengan keterbatasan yang ada, guru mata pelajaran agama Islam selalu berupaya maksimal untuk membiasakan peserta didik disiplin melaksanakan ibadah salat, khususnya salat fardhu secara berjamaah di pesantren.

Upaya yang dilakukan untuk menanamkan nilai-nilai pendidikan Islam pada peserta didik di pesantren Ummusshabri Kota Kendari, yaitu membuat program harian seperti salat fardu berjamaah. Salat fardu berjamaah diwajibkan bagi semua santri yang ada di pesantren Ummusshabri Kota Kendari. Hal ini dilakukan agar santri akan terbiasa ketika nantinya mereka menjadi dewasa.

Meskipun di lapangan ternyata masih ditemukan santri yang main-main bahkan ada yang ditemukan tidak ikut melaksanakan salat berjamaah. Ini mengindikasikan bahwa pelaksanaan salat berjamaah di pesantren Ummusshabri Kota Kendari belum mencerminkan kedisiplinan dan kepatuhan bagi peserta didik atau santri secara menyeluruh. Karenanya bentuk upaya yang dilakukan guru mata pelajaran agama Islam untuk menanamkan nilai-nilai pendidikan Islam pada peserta didik di pesantren Ummusshabri Kota Kendari, yaitu membudayakan kegiatan shalat fardhu berjamah di masjid. Hal ini dilakukan agar peserta didik dapat terbiasa untuk melaksanakan salat berjamaah di masjid sehingga ketika dewasa nantinya tidak berat lagi untuk melaksanakan salat berjamaah.

Pembiasaan dalam hal kebaikan sangat penting untuk dibiasakan bagi anak di masa kecil sehingga ketika nantinya menuju kedewasaan akan menjadi karakter baginya. Seperti halnya masalah salat berjamaah di masjid sangat penting untuk dibiasakan kepada peserta didik di dalam lingkungan pesantren supaya ketika natinya 
keluar dari pesantren maka mereka tetap selalu rajin melaksanakan salat berjamaah karena mereka sudah terbiasa pada waktu mondok di pesantren.

Dapat ditegaskan bahwa upaya penanaman nilai-nilai pendidikan Islam pada peserta didik melalui pendidikan spritual sangat penting ditingkatkan karena di era globalisasi sekarang ini, yang kebanykan mendapat bantuan dari pemerintah adalah pendidikan intelektual, sedangkan pendidikan spritual kurang mendapat perhatian padahal sangat penting karena terkait dengan pembentukan kepribadian dalam bentuk mentalitas dan kejiwaan. Oleh karena itu, penulis berasumsi bahwa dalam upaya mewujudkan nilai-nilai pendidikan Islam pada peserta didik maka harus diintegrasikan tiga pola pendidikan yaitu pendidikan intelektual, spritual dan emosional.

Selain salat berjamaah di pesantren sering pula dilaksanakan salat sunat duha untuk membiasakan kepada peserta didik. Penerapan salat sunat duha di lingkungan pesantren perlu dibudayakan di dalam lingkungan pesantren. Salat sunat duha merupakan salah satu ajaran Rasulullah saw. yang dianjurkan oleh seluruh umatnya untuk dikerjakan, yaitu umat Islam. Salat sunat duha tersebut sangat penting untuk dibiasakan bagi peserta didik sejak anak-anak hingga menuju kedewasaan. Apabila salat sunat duha tersebut dibiasakan kepada peserta didik sejak anak-anak maka tentu akan terbawa nantinya sampai kepada menuju kedewasaan.

Berkaitan dengan hal tersebut, ketika penulis melakukan observasi dan wawancara dari informan yang ada dipesantren Ummu Kota Kendari ditemukan hasil penelitian bahwa salah satu bentuk upaya yang dilakukan oleh guru mata pelajaran agama Islam dalam menanamkan nilai-nilai pendidikan Islam pada peserta didik di Pesantren Ummusshabri Kota Kendari, yaitu membuat program harian dalam bentuk pembiasaan salat sunat duha secara rutin, misalnya shalat dhuha di masjid. Maksud dari kegiatan ini adalah untuk menanamkan nilai-nilai pendidikan Islam pada peserta didik, khususnya dalam hal penanaman sikap kedisiplinan dan kepatuahan dalam mengikuti ajaran Rasulullsh saw. melalui pembiasaan dan pemberian nasehat serta keteladanan melalui contoh dari guru. Dengan begitu maka peserta didik diharapkan dapat memiliki sikap kedisiplinan dan kepatuhan dalam melaksanakan salat sunat dhuha.

Berdasarkan paparan temuan-temuan tersebut di atas, maka dapat dikatakan bahwa upaya yang dilakukan untuk menanamkan 
nilai-nilai pendidikan Islam pada peserta didik sudah termasuk baik, namun ketika penulis melakukan observasi di lapangan ternyata masih ditemukan peserta didik yang bermain-main dalam melaksanakan salat sunat duha dan bahkan ada peserta didik yang sempat tidak ikut melaksanakan salat sunat duha. Pada hal meraka juga tidak berhalangan, hanya saja mereka tidak ikut dengan alasan karena gurunya juga tidak melihat dan tidak memperhatikannya juga. Ini mengindikasikan bahwa pelaksanaan salat sunat duha di pesantren Ummusshabri Kota Kendari, tidak terkontrol dengan baik sehingga belum mampu diterapkan bagi peserta didik secara umum dan secara maksimal.

\section{Menciptakan Lingkungan Santun}

Kesopanan dalam bertutur kata sangat penting dibiasakan oleh peserta didik di dalam lingkungan sekolah. Apabila hal tersebut terbiasa bagi peserta didik maka tentu akan terbawa nantinya di lingkungan manapun mereka berada.

Sehubungan dengan hal tersebut, bentuk penanaman nilai-nilai kesopanan kepada peserta didik dapat digambarkan dalam lingkungan pesantren dimana para peserrta didik dianjurkan untuk selalu bertutur kata dengan baik kepada siapa pun yang ditemani berbicara. Khusus dalam lingkungan pesantren, peserta didik selalu dikontrol pembicaraannya dan apabila ditemukan berbicara yang tidak sopan maka langsung dipanggil untuk diberi nasehat. Apbila peserta didik sudah ditemukan sampai tiga kali berbicara yang tidan sopan maka langsung diberi sanksi yang sifatnya mendidik, misalnya membersihkan ruang guru.

Para guru mata pelajaran agama Islam di pesantren ini selalu mengontrol cara pembicaraan peserta didik di lingkungan pesantren dan apabila kami ditemukan peserta didik yang bertutur kata dengan tidak sopan maka kami langsung dinasehati. Apabila peserta didik tersebut sudah ditegur sampai tiga kali maka tidak ada lagi kebijaksanaan bagibya dan langsung diberi hukuman seperti menbersihkan WC.

Para siswa mengakui bahwa di dalam lingkungan pesantren kami selalu berhati-hati dalam bertutur kata karena guru selalu mengontrol kami dalam bertutur kata dan apabila di antara kami ada yang ditemukan bertutur kata yang tidak sopan maka kami mendapat sanksi. 


\section{Pemberdayaan Organisasi Siswa Intra Sekolah (OSIS)}

Penanaman nilai-nilai tanggung jawab dalam lingkungan pesantren sangat penting bagi peserta didik. Apabila hal tersebut dibiasakan kepada peserta didik maka tentu akan menjadi orang yang bertanggung jawab nantinya ketika diberi amanah.

Bentuk penanaman nilai tanggung jawab kepada peserta didik di dalam lingkungan pesantren yaitu memberikan tugas masing peserta didik untuk dilaksanakan dengan baik. Seperti halnya pembentukan kepengurusan OSIS. Adanya pembentukan kepengurusan OSIS maka dapat melatih peserta didik untuk brtanggung jawab melaksanakan amanah yang diberikan kepadanya. Misalnya peserta didik yang diamanahkan menjadi ketua OSIS, sekretaris, dan bendahara mereka bisa belajar untuk melaksanakan amanah tersebut dengan penuh tanggung jawab. Hal ini diungkap oleh Ismail sebagai kepala sekolah.

Selain pembentukan kepengurusan OSIS masih banyak lagi cara lain yang dilakukan oleh guru mata pelajaran agama Islam untuk menanamkan nilai tanggung jawab kepada peserta didik, seperti memberikan tugas kultum setiap selesai salat.

Kuliah tujuh menit yang dikenal dengan istilah kultum merupakan salah satu bentuk penanaman nilai-nilai pendidikan Islam pada peserta didik yang diprogramkan oleh guru mata pelajaran agama Islam di pesantren Ummusshabri Kota Kendari. Kegiatan tersebut telah dimasukkan ke dalam program harian peserta didik yang dilaksanakan setiap selesai salat zuhur.

Adapun maksud diterapkannya program kegiatan ini adalah untuk melatih dan menanamkan nilai-nilai pendidikan Islam pada peserta didik, khususnya sikap kedisiplinan dalam melaksanakan tugas dan tanggung jawab yang diberikan oleh guru di pesantren. Sehingga ketika mereka dewasa nantinya, untuk melaksanakan hal yang seperti itu tidak merasa berat lagi karena sudah terbiasa. Pelaksanaan kultum tersebut, selalu dikontrol oleh guru dengan baik sehingga peserta didik bersungguh-sungguh dalam melaksanakannya. Bagi peserta didik yang diberi tugas untuk kultum tidak ada alasan untuk menolaknya. Intinya bahwa peserta didik harus mampu semua tampil di depan orang banyak. Apabila kegiatan kultum tersebut selesai maka dilanjutkan dengan doa bersama yang dipimpin langsung oleh guru mata pelajaran agama Islam. 
Peserta didik merasakan bahwa di pesantren Ummusshabri Kota Kendari, setiap selesai salat selalu ditampilkan untuk kultum secara bergilir. Kegiatan ini dilaksanakan secara rutin atau setiap hari. Kemudian setelah itu, dilanjutkan dengan doa bersama.

Penanaman nilai-nilai pendidikan Islam pada peserta didik dalam bentuk kegiatan kultum sangat penting untuk diterapkan bagi peserta didik di dalam lingkungan pesantren karena hal tersebut dapat melatih peserta didik untuk terbiasa tampil di depan umum. Selain itu dapat juga melatih sikap peserta didik yang terkait dengan kedisiplinan dan tanggung jawab dalam melaksanakan tugas yang diberikan kepadanya. Program harian yang dibuat oleh pihak atau warga pesantren Ummusshabri Kota Kendari dalam bentuk kultum, sesungguhnya sangat bagus namun perlu dimaksimalkan pelaksanaannya. Artinya bahwa dalam kegiatan kultum tersebut, peserta didik harus dikontrol dan diatur dengan baik agar semuanya bisa tampil secara bergiliran denga baik. Ketika penulis melakukan observasi langsung di lapangan, ternyata masih ditemukan santri yang diberi tugas kultum tidak siap untuk tampil sehingga terpaksa digantikan oleh temannya yang lain. Ini mengindikasikan bahwa pembina dan guru yang ada di pesantren belum tegas dalam menerapkan kegiatan kultum kepada peserta didik yang ada di pesantren Ummusshabri Kota Kendari.

Berdasarkan paparan di atas, dapat disimpulkan bahwa untuk menanamkan nilai-nilai pendidikan Islam pada peserta didik di lingkungan pesantren, sangat dibutukan sikap kesabaran dan kesungguhan dalam melaksanakannya di samping disertai dengan doa. Walaupun manusia rajin berikhtiar namun apabila tidak disertai dengan tawakkal kepada Allah swt. maka sangat sulit untuk memperoleh sesuatu yang diinginkan. Oleh karena itu, ikhtiar harus sejalan dengan tawakkal.

\section{Membudayakan Kerjasama dan Tolong Menolong}

Kerja sama antara warga masyarakat dengan warga pesantren sangat penting dilakukan dalam upaya menanamkan nilai-nilai pendidikan Islam peserta didik dalam lingkungan pesantren. Salah satu bentuk upaya untuk menanamkan nilai-nilai pendidikan Islam pada peserta didik di Pesantren Ummusshabri Kota Kendari yaitu menjalin kerja sama yang baik antara warga masyarakat dengan warga pesantren dalam mengembangkan nilai-nilai pendidikan Islam. 
Misalnya ketika ada kegiatan dalam lingkungan masyarakat maupun dalam lingkungan pesantren, mereka saling bekerja sama atau saling mengundang dan di situlah salah satu momen yang tepat dala proses penanaman nila-nilai pendidikan Islam peserta didik, khususnya yang terkait dengan sikap kepedulian sosial.

Selain itu, guru mata pelajaran agama Islam dalam menanamkan nilai-nilai pendidikan Islam pada peserta didik di Pesantren Ummusshabri Kota Kendari yaitu melakukan pendekatan atau kerja sama yang baik dengan warga masyarakat. Dalam melakukan pendekatan kepada masyarakat, para pengurus pesantren Ummusshabri di Sulawesi Tenggara Kota Kendari melakukan kegiatan silaturrahim setiap ada kegiatan di dalam lingkungan masyarakat. Melalui kegiatan tersebut para pengurus pesantren Ummusshabri di Sulawesi Tenggara Kota Kendari dapat memanfatkan kesempatan untuk menanamkan nilai-nilai pendidikan Islam pada peserta didik yang ada di Pesantren Ummusshabri Sulawesi Tenggara Kota Kendari.

Kerja sama antara warga masyarakat dengan warga pesantren sangat penting dilakukan dalam upaya menanakan nilai-nilai pendidikan Islam kepada peserta didik, khususnya di pesantren Ummusshabri Sulawesi Tenggara Kota Kendari karena melalui kerjasama tersebut maka dapat memberi peluang untuk melakukan pendekatan kepada masyarakat sehingga akan memudahkan dalam memberi pemahaman kepada masyarakat mengenai pentingnya penanaman nilai-nilai pendidikan Islam terhadap peserta didik.

Salah satu upaya yang harus dilakukan dalam menanamkan nilai-nilai pendidikan Islam pada peserta didik di Pesantren Ummusshabri Sulawesi Tenggara Kota Kendari yaitu menjalin hubungan kerja sama yang baik, khususnya ketika ada kegiatan atau acara yang dilakukan oleh warga masyarakat, sebaiknya ikut juga berpartisipasi dalam kegiatan tersebut sehingga di situlah kesempatan untuk melakukan pedekatan kepada masyarakat di samping memperbaiki silaturrahim. Dengan begitu maka tentu akan memudahkan untuk mengembangkan nilai-nilai pendidikan Islam kepada peserta didik sehingga hubungan antara peserta didik dengan masyarakat sekitar pesantren semakin harmonis.

Dapat disimpulkan bahwa bentuk upaya menanamkan nilainilai pendidikan Islam pada peserta didik di Pesantren Ummusshabri Sulawesi Tenggara Kota Kendari yaitu melakukan kerjasama yang 
baik antara warga masyarakat dengan para pengurus pesantren Ummusshabri di Sulawesi Tenggara Kota Kendari. Kerjasama yang dimaksudkan di sini adalah saling membantu dan mengunjungi ketika ada kegiatan yang dilakukan, baik kegiatan yang dilakukan dalam lingkungan masyarakat maupun kegiatan yang dilakukan dalam lingkungan pesantren. Melaui kegiatan tersebut, para pengurus pesantren Ummusshabri di Sulawesi Tenggara Kota Kendari memiliki kesempatan untuk melakukan pedekatan kepada masyarakat sehingga dapat memberikan pemahaman tentang pentingnya nilai-nilai pendidikan Islam antara masyarakat setempat dengan peserta didik atau warga pesantren yang ada di sekitarnya.

Selain kegiatan tersebut, bentuk kegiatan lainnya yang dilakukan oleh para pengurus pesantren Ummusshabri dalam mengoptimalkan nilai-nilai pendidikan Islam pada masyarakat di Sulawesi Tenggara Kota Kendari, di antaranya adalah membuka kegiatan amal usaha ekonomi.

Pengurus pesantren Ummusshabri dalam menaamkan nilainilai pendidikan Islam pada peserta didik di Pesantren Ummusshabri Sulawesi Tenggara Kota Kendari yaitu membuka kegiatan amal usaha ekonomi. Kegiatan amal usaha ekonomi sudah di mulai seiring dengan lahirnya pesantren tersebut melalui koperasi yang berada di setiap asrama putra dan putri. Pada saat itu, peruntukaan aktivitas koperasi, sebatas melayani kebutuhan belanja santri putra dan putri. Dengan demikian kegiatan amal usaha ekonomi amatlah terbatas. Mulai tahun 1995, dengan diresmikannya "Waserda" kegiatan amal usaha ekonomi pesantren semakin luas dan melayani kebutuhan masyarakat Kota Kendari. Letaknya di pinggir jalan protokol dan membuat aktivitas perekonomian di pesantren tersebut cukup menggeliat.

Pengurus pesantren Ummussobri dalam menanamkan nila-nilai pendidikan Islam pada peserta didik di Pesantren Ummusshabri Sulawesi Tenggara Kota Kendari adalah membuat kegiatan amal usaha ekonomi. Dari hasil usaha tersebut dimanfaatkan sebagian untuk membantu peserta didik yang kurang mampu dan para anak yatim piatu melalui lembaga panti asuhan.

Kegiatan amal usaha ekonomi yang diterapkan oleh para pengurus pesantren Ummussobri sangat penting untuk dikembangkan dalam rangka membantu peserta didik dan warga masyarakat yang kurang mampu. Kegiatan amal usaha ekonomi tersebut merupakan salah satu bentuk daripada penanaman nilai-nilai pendidikan Islam. 
Membantu kebutuhan ekonomi peserta didik dan warga masyarakat merupakan upaya untuk mengatasi terjadinya kemiskinan sehingga hal tersebut sengat penting dilakukan untuk mensejahterakan warga masyarakat dan membantu peserta didik yang kurang mampu. Selain itu, juga sering diadakan kegiatan pengajian bulanan. Kegiatan pengajian bulanan yang dilakukan dalam bentuk program bulanan merupakan salah satu bentuk upaya yang dilakukan oleh guru mata pelajaran agama Islam dalam menanamkan nilai-nilai pendidikan Islam pada peserta didik di pesantren Ummusshabri Kota Kendari.

Adapun teknik pelaksanaannya sebagaimana yang diungkapkan oleh Kamrin bahwa pengajian bulanan tersebut, dilaksanakan melalui kerjasama antara guru mata pelajaran agama Islam dengan peserta didik khususnya pengurus OSIS yang ada di pesantren Ummusshabri Kota Kendari. Selain itu, kegiatan ini biasanya juga daihadiri oleh allumni. Umumnya orang luar yang bergabung dalam kegiatan ini adalah para alumni dan mantan pengurus OSIS masih tetap concern dan peduli dengan upaya pembinaan remaja atau peserta didik di Pesantren Ummusshabri Kota Kendari. Durasi pengajian setiap pertemuan berkisar antara dua hingga tiga jam. Arah pembinaan difokuskan pada penanaman wawasan keislaman dan pembiasaan nilai-nilai akhlak mulia kepada peserta didik, seperti kedisiplinan, kepatuhan, kesopanan, kepedulian sosial dan lain sebagainya. Adapun pembawa materi dalam pengajian ini adalah diambil salah seorang ustadz dari luar yang dianggap berkompeten dalam menanamkan nilai pendidikan Islam pada peserta didik. Dalam kegiatan pengajian ini dibentuk panitia khusus dan di situlah peserta didik kerjasama dan tolong-menolong dalam melaksanakan tugas yang diberikan masing-masing kepadanya.

Sebelum kegiatan pengajian tersebut dimulai, ustadz yang akan membawakan materi pengajian, terlebih dahulu melakukan konfirmasi kepada guru mata pelajaran agama Islam mengenai materi yang akan diberikan kepada peserta didik. Hal ini dimaksudkan agar arah pembahasan materi dalam pengajian tersebut lebih efektif dan efisien. Sehingga dengan begitu maka kegiatan pengajian tersebut akan lebih terarah sesuai dengan kebutuhan peserta didik.

Peserta didik menerangkan bahwa di Pesantren ini selalu diadakan kegiatan pengajian bulanan. Dalam kegiatan ini dihadiri oleh banyak peserta didik termasuk dalam hal ini adalah peserta didik berasal dari allumi di pesantren ini. Setiap bulan, di pesantren 
ini selalu mengadakan pengajian tentang ilmu keislaman. Dalam kegiatan ini dikontrol langsung oleh guru mata pelajaran agama Islam.

Pengajian bulanan yang dilakukan oleh peserta didik melalui kerja sama dengan guru mata pelajaran agama Islam di pesantren Ummusshabri Kota Kendari, merupakan salah satu kesempatan untuk dapat menanamkan nilai-nilai pendidikan Islam kepada peserta didik. Melalui kesempatan tersebut, guru mata pelajaran agama Islam dapat melakukan berbagai macam pendekatan kepada peserta didik, khsusnya dalam hal penanaman nilai-nilai pendidikan Islam. Oleh karena itu, pengajian bulanan sangat penting dilakukan di lingkungan pesantren dalam upaya menanamkan nilai pendidikan Islam pada peserta didik.

Berkaitan dengan program bulanan yang dilaksanakan di pesantren Ummusshabri Kota Kendari, penulis sepakat akan tetapi kegiatan tersebut masih perlu dimaksimalkan pelaksanaannya sehingga dapat berjalan dengan lebih eektif dan efisien. Artinya bahwa dalam melakukan kegiatan pengajian tersebut, sebaiknya dibentuk beerapa panitia khusus dari guru yang bisa dan mampu mengawasi jalannya kegiatan tersebut karena pada saat kegiatan pengajian berlangsung masih ada yag ditemukan peserta didik yang selalu keluar masuk, selalu berbicara dengan temannya di luar dari pembahasan pengajian tersebut.

\section{Pembahasan}

Nilai-Nilai pendidikan agama Islam yang ditanamkan pada peserta didik di Pondok Pesantren Ummusshabri mewujud dalam bentuk: Kedisiplinan, Kesopanan, Tanggung Jawab, dan Kepedulian Sosial. Empat nilai tersebut sesungguhnya digali dari sumber utama ajaran agama Islam, yakni Al-Qur'an dan Sunnah Rasul.

\section{Kesiplinan}

Secara teologis, tema kedisiplinan mendapatkan sinyalemen dalam sumpah-sumpah (qasam) Tuhan mengenai waktu, misalnya $W a$ Al'Ashri atau demi waktu ashar, Wa Alfajri atau demi waktu fajar, Wa Allaili atau demi malam, dan Wa Aldhuha atau demi waktu matahari sepenggalahan naik ${ }^{10}$. Sumpah-sumpah Tuhan yang menunjukkan

10 Departemen Agama, R. I. "Al-Qur'an dan terjemahan." Jakarta: PT Syaamil Cipta Media (2005). 
waktu tersebut adalah pertanda pentingnya waktu, dimana mereka yang menyia-nyiakan waktu dianggap orang merugi. Memanfaatkan waktu sebaik-baiknya berhubungan erat dengan persoalan keimanan.

Persoalan kedisiplinan telah mendapatkan perhatian dari banyak kalangan untuk melakukan pendalaman secara empirik. Tema kedisiplinan dapat menjangkau berbagai variabel dalam perkembangan peserta didik, bahkan ketika memasuki dunia kerja.

Prestasi belajar siswa dapat dipengaruhi oleh variabel kedisiplinan $^{11}$, demikian pun dengan hasil belajar ${ }^{12}$. Kedisiplinan dapat memengaruhi kinerja ${ }^{13}$. Meskipun temuan-temuan empirik tersebut berada pada medan yang bervariasi, tetapi bagi peserta didik di Pondok Pesantren Ummusshabri khususnya dapat menjadi pemantik motivasi untuk lebih meningkatkan kedisiplinan karena berguna untuk kehidupan mereka setelah keluar dari pondok.

Kedisiplinan berhubungan dengan konsep diri ${ }^{14}$ dan pembentukan karakter ${ }^{15}$. Karenanya kedisiplinan mesti dibina melalui pendidikan dan pengalaman jangka panjang $^{16}$, menciptakan iklim

11 Prasojo, Retmono Jazib. "Pengaruh Perhatian Orang Tua Dan Kedisiplinan Belajar Terhadap Prestasi Belajar Mata Pelajaran IPS." Ekonomi IKIP Veteran Semarang 2, no. 1 (2014). Lihat juga Arisana, Arga Lacopa, and Ismani Ismani. "Pengaruh Kedisiplinan Siswa dan Persepsi Siswa tentang Kualitas Mengajar Guru terhadap Prestasi Belajar Akuntansi Siswa Kelas XI IPS MAN Yogyakarta II Tahun Ajaran 2011/2012." Jurnal Pendidikan Akuntansi Indonesia 10, no. 2 (2012).

12 Sobri, Muhammad, and Moerdiyanto Moerdiyanto. "Pengaruh Kedisiplinan dan Kemandirian Belajar terhadap Hasil Belajar Ekonomi Madrasah Aliyah di Kecamatan Praya." Harmoni Sosial: Jurnal Pendidikan IPS 1, no. 1 (2014).

${ }^{13}$ Arianto, Dwi Agung Nugroho. "Pengaruh kedisiplinan, lingkungan kerja dan budaya kerja terhadap kinerja tenaga pengajar." Jurnal Economia 9, no. 2 (2013): 191-200. Lihat jugaDwipasari, Lita. "Kompensasi dan kedisiplinan sebagai faktor yang berpengaruh terhadap kinerja dan kepuasan kerja karyawan bank." Jurnal Keuangan dan Perbankan 12, no. 3 (2008): 494-503.

${ }^{14}$ Reski, Niko, Taufik Taufik, and Ifdil Ifdil. "Konsep diri dan kedisiplinan belajar siswa." Jurnal EDUCATIO: Jurnal Pendidikan Indonesia 3, no. 2 (2017): 85-91.

15 Yasin, Fatah. "Penumbuhan kedisiplinan sebagai pembentukan karakter peserta didik di madrasah." el-hikmah 1 (2013).

16 Oktafiyani, Yuyun. "Pengaruh Pendidikan dan Masa Kerja Terhadap Kedisiplinan Karyawan di SMK Muhamadiyah Surakarta." PhD diss., Universitas Muhammadiyah Surakarta, 2009. 
organisasi yang kondusif ${ }^{17}$, pemberian reward $^{18}$, pelaksanaan tata tertib $^{19}$, dan keterlibatan berorganisasi ${ }^{20}$. Upaya lain yang dapat dilakukan bagi peserta didik yakni melalui metode bercerita, dimana guru menceritakan kisah-kisah yang berkaitan dengan kesuksesan orang-orang yang disiplin ${ }^{21}$. Selain itu, kedisiplinan dapat dibina oleh guru melalui bimbingan kelompok dengan teknik modeling ${ }^{22}$.

\section{Kesopanan}

Persoalan kesopanan merupakan tema penting yang ada dalam ajaran agama Islam. Al Qur'an dan Assunnah menunjukkan berbagai ungkapan tentang kesopanan seperti lembah lebut ${ }^{23}$, berkata baik ${ }^{24}$, menghormati orang tua ${ }^{25}$, memuliakan tamu ${ }^{26}$, dan tata krama dalam majelis $^{27}$. Masih banyak lagi ungkapan-ungkapan yang menunjuk pada kesopanan dalam Al Qur'an, termasuk hubungan dengan pemerintah.

Hal ini berarti bahwa kesopanan adalah aspek penting dalam akhlak seorang Islam yang bertugas membawa kedamaian, dan rahmat bagi alam semesta. Kesopanan lebih nampak dalam bertutur kata,

${ }^{17}$ Amriany, Fifi, Yusti Probowati, and Gunadi Atmadji. "Iklim organisasi yang kondusif meningkatkan kedisiplinan kerja." Anima. Indonesian Psychological Journal 19, no. 2 (2004): 179-193.

${ }^{18}$ Mufidah, Umri. "Efektivitas Pemberian Reward Melalui Metode Token Ekonomi Untuk Meningkatan Kedisiplinan Anak Usia Dini." PhD diss., Universitas Negeri Semarang, 2013.

${ }^{19}$ Hadianti, Leli Siti. "Pengaruh Pelaksanaan Tata Tertib Sekolah Terhadap Kedisiplinan Belajar Siswa (Penelitian Deskriftif Analisis di SDN Sukakarya II Kecamatan samarang Kabupaten Garut)." Jurnal Pendidikan UNIGA 2, no. 1 (2017): 1-8.

20 Afiani, Yanuarini Esha, Slamet Sumarto, and Moh Aris Munandar. "Penanaman Kedisiplinan Melalui Kegiatan Kepramukaan di SMA N 1 Kutowinangun." Unnes Civic Education Journal 2, no. 1 (2016).

21 John, Eltin. "Upaya Meningkatkan Kedisiplinan Anak di Kelas melalui Cerita." Jurnal Pendidikan Penabur (2011): 11-25.

22 Roshita, Ita. "Meningkatkan Kedisiplinan Siswa Melalui Layanan Bimbingan Kelompok dengan Teknik Modeling." Jurnal Penelitian Tindakan Kelas 15 , no. 4 (2014).

${ }^{23}$ QS. Ali Imran: 159

${ }^{24}$ QS. Al Baqarah: 263

${ }^{25}$ QS. Al Isra' : 23-24

${ }^{26}$ QS. Al Hijr : 67-69

${ }^{27}$ QS. Al Mujadalah : 11 
selanjutnya dalam perilaku. Bahkan dalam konteks orang Indonesia, kesopanan dalam bertutur menjadi ciri yang mudah dikenali ${ }^{28}$. Beberapa etnik di nusantara menjadikan kesopanan berbahasa sebagai strategi untuk menunjukkan karakteristik atau identitas kesukuan, sebagaimana dipraktikkan oleh orang Bugis Pinrang ${ }^{29}$. Bagi perempuan Jawa, strategi kesopanan ditunjukkan pada aspek positif maupun negatif, sehingga mereka menjadi lebih mudah bergaul dengan sesama jenis maupun lawan jenis, juga dapat mengungkapkan permintaan maaf atas perilaku yang dianggap kurang pantas ${ }^{30}$.

\section{Tanggung Jawab}

Tanggung jawab adalah keberanian melakukan sesuatu karena kepercayaan dari orang lain, ataupun terkait dengan ucapan dan perbuatan yang menuntut ditunaikan. Indikasi-indikasi dalam AlQur'an cukup banyak mengenai tanggung jawab, misalnya sikap Nabi Ismail as yang ikhlas menerima perintah Tuhan dan kehendak Nabi Ibrahim as ${ }^{31}$.

\section{Kepedulian Sosial}

Kepedulian sosial terhubung kuat dengan rukun Islam, yakni mengeluarkan zakat dan variannya dalam bentuk wakaf, infaq, dan shadaqah $^{32}$. Kondisi sosial yang membagi masyarakat menjadi dua kutub ekstrim "kaya miskin" membutuhkan solusi agar tidak menciptakan kesenjangan yang semakin besar. Kepedulian sosial merupakan faktor dasar yang mesti dibangun sejak dini, terutama pada peserta didik.

28 Manaf, Ngusman. "Kesopanan tindak tutur menyuruh dalam bahasa Indonesia." LITERA 10, no. 2 (2011).

29 Achmad, Syarifuddin. "Strategi kesopanan berbahasa masyarakat bugis pinrang provinsi sulawesi selatan." Bahasa dan Seni: Jurnal Bahasa, Sastra, Seni, dan Pengajarannya 40, no. 1 (2012).

${ }^{30}$ Sudartini, Siti. "Konsep kesopanan berbicara oleh wanita dalam budaya Jawa." Widyaparwa 38, no. 1 (2010): 27-34.

${ }^{31}$ QS. Ash-Shaffat: 102 \& QS. Al-Mudatsir: 38.

${ }^{32}$ QS. Al Baqarah: 3 \& 43 ; At- Taubah: 103 


\section{Kesimpulan}

Ajaran Islam ditujukan untuk umat manusia seluruhnya, sehingga membutuhkan transfer nilai-nilai kepada manusia. Tidak bersifat insidental, tetapi melalui proses pewarisan yang tertata pada lembaga pendidikan. Lembaga pesantren memiliki tugas penting, bahkan menjadi unjuk tombak utama dalam penanaman nilai-nilai ajaran Islam. Pesantren Ummusshabri menunjukkan konsistensi menjaga nilai-nilai pendidikan Islam seperti: kedisiplinan, kesopanan, tanggung jawab, dan kepedulian sosial. Upaya menjadi dan mengembangkan nilai-nilai Islam tersebut dilakukan melalui: pengawasan dan sanksi edukatif, pembiasaan, membangun lingkungan santun, pemberdayaan OSIS, dan membudayakan kerjasam dan tolong menolong. 


\section{Daftar Pustaka}

Achmad, Syarifuddin. "Strategi kesopanan berbahasa masyarakat bugis pinrang provinsi sulawesi selatan." Bahasa dan Seni: Jurnal Bahasa, Sastra, Seni, dan Pengajarannya 40, no. 1 (2012).

Afiani, Yanuarini Esha, Slamet Sumarto, and Moh Aris Munandar. "Penanaman Kedisiplinan Melalui Kegiatan Kepramukaan di SMA N 1 Kutowinangun." Unnes Civic Education Journal 2, no. 1 (2016).

Amriany, Fifi, Yusti Probowati, and Gunadi Atmadji. "Iklim organisasi yang kondusif meningkatkan kedisiplinan kerja." Anima. Indonesian Psychological Journal 19, no. 2 (2004): 179-193.

Arianto, Dwi Agung Nugroho. "Pengaruh kedisiplinan, lingkungan kerja dan budaya kerja terhadap kinerja tenaga pengajar." Jurnal Economia 9, no. 2 (2013): 191-200.

Arisana, Arga Lacopa, and Ismani Ismani. "Pengaruh Kedisiplinan Siswa dan Persepsi Siswa tentang Kualitas Mengajar Guru terhadap Prestasi Belajar Akuntansi Siswa Kelas XI IPS MAN Yogyakarta II Tahun Ajaran 2011/2012." Jurnal Pendidikan Akuntansi Indonesia 10, no. 2 (2012).

Bungin, Burhan. Penelitian kualitatif: komunikasi, ekonomi, kebijakan publik, dan ilmu sosial lainnya. Kencana, 2007.

Daradjat, Zakiah, A. Sadali, Yusuf Amer Feisal, Zaini Muchtarom, M. Abduh Malik, and Ahmad Basyar. Dasar-dasar agama Islam: buku teks pendidikan agama Islam pada perguruan tinggi umum. Bulan Bintang, 1984.

Departemen Agama, R. I. "Al-Qur'an dan terjemahan." Jakarta: PT Syaamil Cipta Media (2005).

Dwipasari, Lita. "Kompensasi dan kedisiplinan sebagai faktor yang berpengaruh terhadap kinerja dan kepuasan kerja karyawan bank." Jurnal Keuangan dan Perbankan 12, no. 3 (2008): 494503.

Hadianti, Leli Siti. "Pengaruh Pelaksanaan Tata Tertib Sekolah Terhadap Kedisiplinan Belajar Siswa (Penelitian Deskriftif Analisis di SDN Sukakarya II Kecamatan samarang Kabupaten Garut)." Jurnal Pendidikan UNIGA 2, no. 1 (2017): 1-8. 
John, Eltin. "Upaya Meningkatkan Kedisiplinan Anak di Kelas melalui Cerita." Jurnal Pendidikan Penabur (2011): 11-25.

Manaf, Ngusman. "Kesopanan tindak tutur menyuruh dalam bahasa Indonesia." LITERA 10, no. 2 (2011).

Miles, Matthew B., and A. Michael Huberman. Analyzing qualitative data: A sourcebook of new methods. Center for Policy Research, 1983.

Moleong, Lexy J. "Metodologi penelitian kualitatif edisi revisi." Bandung: PT Remaja Rosdakarya 103 (2007).

Mufidah, Umri. "Efektivitas Pemberian Reward Melalui Metode Token Ekonomi Untuk Meningkatan Kedisiplinan Anak Usia Dini." PhD diss., Universitas Negeri Semarang, 2013.

Oktafiyani, Yuyun. "Pengaruh Pendidikan dan Masa Kerja Terhadap Kedisiplinan Karyawan di SMK Muhamadiyah Surakarta." PhD diss., Universitas Muhammadiyah Surakarta, 2009.

Prasojo, Retmono Jazib. "Pengaruh Perhatian Orang Tua Dan Kedisiplinan Belajar Terhadap Prestasi Belajar Mata Pelajaran IPS." Ekonomi IKIP Veteran Semarang 2, no. 1 (2014).

Reski, Niko, Taufik Taufik, and Ifdil Ifdil. "Konsep diri dan kedisiplinan belajar siswa." Jurnal EDUCATIO: Jurnal Pendidikan Indonesia 3, no. 2 (2017): 85-91.

Roshita, Ita. "Meningkatkan Kedisiplinan Siswa Melalui Layanan Bimbingan Kelompok dengan Teknik Modeling." Jurnal Penelitian Tindakan Kelas 15, no. 4 (2014).

Sobri, Muhammad, and Moerdiyanto Moerdiyanto. "Pengaruh Kedisiplinan dan Kemandirian Belajar terhadap Hasil Belajar Ekonomi Madrasah Aliyah di Kecamatan Praya." Harmoni Sosial: Jurnal Pendidikan IPS 1, no. 1 (2014).

Sudartini, Siti. "Konsep kesopanan berbicara oleh wanita dalam budaya Jawa." Widyaparwa 38, no. 1 (2010): 27-34.

Sugiyono, Prof. "Dr. 2010." Metode Penelitian Kuantitatif, Kualitatif, dan R\&D. Bandung: CV Alfabeta.

Syahrul, Syahrul. "Kepemimpinan dan Inovasi Lembaga Pendidikan (Pengalaman Pondok Gontor VII Putra Sulawesi Tenggara)." Al-Ta'dib 8, no. 1 (2015): 82-100.

Syahrul, Syahrul. "Perjumpaan Demokrasi, Multikulturalisme dan Inklusifisme Pendidikan di PM Gontor 7 Putera, Konawe Selatan." Shautut Tarbiyah 38, no. 24 (2018): 163-180. 
Syahrul, Syahrul, RELIGIO-TRANSFORMASIONAL, K. E. P. E. M. I. M. P. I. N. A. N., SYAHRUL MARHAM, and IHWAN FAUZI. "EKSEKUTIF SUMMARY."

Syahrul, Marham, Syahrul. "Full Day School: Kontroversi Dan Fenomena Kebangkitan Pendidikan Berbasis Masyarakat Di Kota Kendari.” OSF, June 2, 2019. osf.io/wkc8b.

Yasin, Fatah. "Penumbuhan kedisiplinan sebagai pembentukan karakter peserta didik di madrasah." el-hikmah 1 (2013). 